\title{
Correlations between Plasma Sphingosine-1-phosphate (S1P) and Gene Expression of S1P Receptors with Mogenic Regulatory Factors Following Resistance Training
}

\author{
Ebrahim Banitalebi ${ }^{1}$, Reza Gharakhanlou ${ }^{2}$ \\ ${ }^{1}$ Assistant professor in exercise physiology, University of Shahrekord. Shahrekord, Iran. \\ ${ }^{2}$ Associate professor in Exercise Physiology, Department of Sport Sciences, Tarbiat Modares University, Tehran, Iran.
}

Received: 4 Feb 2016

Revised : 5 Mar 2016

Accepted: 27 Mar 2016

Corresponding Author: Ebrahim Banitalebi

Assistant professor in exercise physiology, University of Shahrekord. Shahrekord. Iran.

Phone: +983832326385

E-mail: banitalebi.e@gmail.com

\begin{abstract}
Background: The purpose of present study was to investigate whether Sphingosine 1-phosphate (S1P) levels and its receptors gene expressions are correlated with MyoD and myogenin following resistance training.

Materials and Methods: 24 eight-week-old male Wistar rats (190-250 gr) were randomly assigned into a control $(n=12)$ or training $(n=2)$ group. The rats climbed a resistance training ladder with weights attached to their tails. The content of plasma S1P and relative mRNA expression was determined by high performance liquid chromatography (HPLC) and Real-time PCR, respectively.

Results: Resistance training increased the content of S1P in plasma $(\mathrm{P}=0.001)$ and changed the gene expression of S1P1, S1P2 and S1P3 receptors. There were significant correlations between plasma $\mathrm{S} 1 \mathrm{P}$ and gene expression of $\mathrm{S} 1 \mathrm{P} 2,3$ receptors with gene expression of MyoD.

Conclusion: S1P as a growth mediator may play an important role in skeletal muscle adaptations.
\end{abstract}

Keywords: MyoD, Myogenin; S1P; S1P receptor; Skeletal muscle

Please cite this article as: Banitalebi E, Gharakhanlou R. Correlations between Plasma Sphingosine-1-phosphate (S1P) and Gene Expression of S1P Receptors with Mogenic Regulatory Factors Following Resistance Training. Res Mol Med. 2016; 4 (2): $30-35$

\section{Introduction}

Skeletal muscle has a high degree of metabolic, structural, contractile and functional plasticity (1). Several growth factors have been shown to affect satellite cells activation and proliferation (2). It has been shown that MyoD and myogenin, as members of myogenic regulatory factors (MRFs) family (3), are myogenic markers of satellite cells activation and are believed to be involved in satellite stem cells proliferation and differentiation, respectively (4). Sphingolipids (sphingosine, sphingosine-1-phosphate (S1P), sphinganine, sphingosine-1-phosphocholine ( $\mathrm{S} 1 \mathrm{PCh})$, ceramide and ceramid-1-phosphate) (5) are involved in regulation of proliferation, differentiation, hypertrophy and apoptosis of cells $(5,6) . \mathrm{S} 1 \mathrm{P}$ is a platelet-derived sphingolipid $(7,8)$ that acts as an extracellular mediator through (9) G protein-coupled receptors family (10) S1P1 (EDG-1), S1P2 (EDG-5), S1P3 (EDG-3), S1P4 (EDG-6), and S1P5 (EDG-8)
(9). S1P receptors couple to different heterotrimeric G proteins including Gi, q, 12/13 (11). S1P can act through the activation of phospholipase C (PLC), $\mathrm{Ca} 2+$ mobilization, activation of extracellular signal regulated kinases 1/2 (ERK1/2), mitogen-activated protein kinase (MAPK), adenylate cyclase (AC), phosphoinositide 3-kinase (PI3K), small GTPases Rac and Rho, protein kinases Akt, c-Jun N-terminal kinase (JNK), phospholipase D (PLD), and inducing cellular calcium flux and inhibiting cAMP accumulation. S1P1, 2, 3 receptors levels of skeletal muscle are high, among which S1P1 expresses at the highest level (12). Interestingly, following denervation, infusion of S1P and sphingosine increased myoD and myogenin (12). Nagata showed that S1P has an important role in muscular regeneration through regulation of skeletal muscle satellite cells $(13,14)$. Kim et al. strongly suggest that S1P can affect the 
chondrocyte proliferation (15).

S1P can act as a myogenic differentiation factor through P38MAPK pathway (16). Following injury in skeletal muscle cells SK1 enzyme was activated and caused the increase of levels of endogenous S1P that associated to satellite cells proliferation and differentiation (17). Donati et al. demonstrated the role of S1P inproliferation and survival of mesoangioblast and believed that S1P-dependent signaling pathways may be involved in improvement of muscle repair and regeneration (18). Furthermore, Danieli-Betto et al showed that exogenous S1P stimulates the process of myofibers regeneration. Recently Lou et al illustrated that in dystrophic muscles S1P enhances satellite cell activation through a S1PR2/STAT3 Signaling Pathway. S1P influences epigenetic reprogramming in regenerating muscle (19).

These modifications suggest that S1P signaling is involved in the molecular events which control the early stages of injured muscles repair. In the same line some studies have indicated the bioactive lipid $\mathrm{S} 1 \mathrm{P}$ as a novel myogenic factor and have implied to the involvement of sphingolipid pathways in muscle growth (20). Danieli-Betto et al showed that prolonged exercise increases the content of S1P in the soleus and the red gastrocnemius, so they expressed that S1P could be a factor to delay muscle fatigue during long-term exercise (21). To the best of our knowledge, there is no evidence on relation between myogenic markers of satellite cell activation (MyoD and myogenin) and plasma S1P and gene expression of its receptors. Considering the importance of load training as a stimulating model of muscle adaptation, this research aimed at studying possible relations between myogenic regulatory factors and S1P system in skeletal muscles of rat.

\section{Materials and Methods \\ Animals and Protocol training}

Twenty four 8-week-old male Wistar rats (190-250 gr) were obtained from Pasture institute (Tehran, Iran). All animals were maintained in pairs in a temperature and humidity controlled Room at $22{ }^{\circ} \mathrm{C}$ under a 12:12-h light-dark cycle and were allowed normal cage activity. They were fed with standard rat diet and water was also available. After a week of acclimation to the animal facility, the rats were randomly divided into a control group $(\mathrm{n}=12)$ and a training group $(n=12)$. The control group remained in cages during the experimental period. Body weight of both groups were monitored weekly and served as a general indicator of the health of the animals. Resistance training ladder was one meter height with $2 \mathrm{~cm}$ grid and 85 degree incline (22).

After one week familiarizing with resistance training, exercise started using weights attached to the upper portion of base of rat's tail. The second week began with a load $50 \%$ of their individual body mass (23). The load was then increased by $200 \%$ of their body mass at the end of 8th week.

A successful repetition was when the animal climbed from the bottom of the rack to the top within 8 seconds. The rats were placed at the bottom of the ladder and motivated to climb the resistance ladder. The only encouragement during the training period was an occasional touch of the base of the animal's tail (24). The number of climbs (repetitions) performed was 20 repetitions per session. After finishing one set ( 5 repetitions) rest was permitted for 2 minutes. The animals performed each 5 repetitions of each set with $15 \mathrm{~s}$ rest between each repetition. The rats trained 3 days/week for 8 weeks. A warm-up program consisting of two sets of five repetitions (with no weight), with a 3 minutes rest between sets was performed by animals. At the end of each session, the rats completed a cool-down consisting of five repetitions (with no weight), with 3 minutes rest between sets.

\section{Measurements}

The content of S1P was determined by high pressure liquid chromatography (HPLC) with a fluorescence detector and $\mathrm{C} 18$ reversed-phase column system (Aligent 1200 series. NanoLC) (25). S1P and C17S1P (a 17 carbon analog of S1P as internal standard) were obtained from Avanti Polar Lipids (Alabaster, AL). O-phthalaldehyde (OPA) (suitable for HPLC fluorimetric detection) and Alkaline Phosphatase were obtained from Sigma-Aldrich. Other solutions such as HPLC-grade water, acetonitrile, $\beta$ Mercaptoethanol/2-Mercaptoethanol (2ME), ethanol and Methanol were purchased from Merck (Homburg, Germany) (25).

All surgical procedures were done in a single session. The rats were anesthetized by an intraperitoneal injection of Ketamine $(75 \mathrm{mg} / \mathrm{kg})$ and Xylazine $(20 \mathrm{mg} / \mathrm{kg})$ after the 8 weeks of resistance training and $48 \mathrm{~h}$ after the last exercise bout to avoid the acute effects of training. The soleus muscle as a slow twitch muscle was removed and studied. The blood samples were spun down in a centrifuge for $15 \mathrm{~min}$ at $4{ }^{\circ} \mathrm{C}$ temperature and $8000 \mathrm{~g}$ to remove the blood cells. Plasma and muscles were frozen in liquid nitrogen and stored in $-80{ }^{\circ} \mathrm{C}$ for later analysis.

Total RNA was isolated from $\sim 50 \mathrm{mg}$ muscles of soleus that were powdered under liquid nitrogen using a pestle. Frozen powder was incubated in $1 \mathrm{ml}$ Trizol reagent. Then The RNA samples were stored at $-80{ }^{\circ} \mathrm{C}$ until later analysis. $2 \mu \mathrm{g}$ of total RNA was used to synthesize cDNA using a Kit (Fermentase). Determination of relative mRNA expression was performed by real-time RT-PCR using a Real-Time 
PCR Detection System (Applied Biosystems StepOnePlus ${ }^{\mathrm{TM}}$ Real-Time PCR System (48 well)).

Table 1. The weight before and after training, and amount of plasma S1P content

\begin{tabular}{lllll}
\hline Groups & Exercise Group (N= 12) & Control Group (N = 12) & t & P - value \\
\hline Pre-training weight (gr) & $223.25 \pm 11.95$ & $224.41 \pm 15.77$ & 0.204 & 0.840 \\
Post-training weight (gr) & $285.83 \pm 18.50$ & $280.58 \pm 16.20$ & 0.739 & 0.467 \\
Plasma S1P (pmol/ml) & $1016.38 \pm 461.01$ & $430.43 \pm 195.39$ & 4.054 & $0.001 * *$ \\
\hline
\end{tabular}

The forward $(\mathrm{F})$ and reverse $(\mathrm{R})$ primer sequences for 18S, S1P1, S1P2, S1P3 were as following: 18S -F: GTTGGTTTTCGGAACTGAGGC, R: GTCGGCAT CGTTTATGGTCG (204bp), S1P1 (NM-017301) - F: TCATCGTCCGGCATTACAACTA, R: GAGTGA GCTTGTAGGTGGTG (273bp), S1P2 (NM-01719 2)-F: CGGAGGCACTGACTAATCAGATT, R: TC CCAGCACTCAGGACACAGTTA (278pb), S1P3 (XM-225216)-F: ACGCGCGCATCTACTTC CT, R: TGGATCTCTCGGAGTTGTGGTT (69bp), MyoD (NM-176079)-F: ACTACAGCGGCGACTCAGAC, R: GTGGAGATGCGCTCCACTAT (208bp), myogenin (NM-017115)-F: TGGTCCCAACCCA GGAGATC ATTT, R: ACATATCCTCCACCGTGA TGCTGT (233bp).

The total volume of the reaction tube was $20 \mu \mathrm{l} ; 10 \mu \mathrm{l}$ SYBR Green Master Mix (primer Design, UK), 1.4 $\mu l$ forward and reverse primers, $5 \mu 1$ nuclease-free water and $3.6 \mu \mathrm{L}$ cDNA template. The amplification profile included a denaturation step at $95^{\circ} \mathrm{C}$ for $15 \mathrm{~s}$, primer annealing at $60^{\circ} \mathrm{C}$ for $15 \mathrm{~s}$ and $30 \mathrm{~s}$ at $72{ }^{\circ} \mathrm{C}$ with 40 cycles ( 3 steps), and extension at $72{ }^{\circ} \mathrm{C}$ for $60 \mathrm{~s}$. All samples were run in duplicate. Relative fold changes in mRNA were determined by the deltadelta cycle threshold method after normalizing to the internal control gene. 18s rRNA was used as a control to normalize the mRNA content of the target genes in each sample (26).

\section{Statistical analysis}

The findings were analyzed using Pearson correlation and independent t-tests. The results are presented as mean \pm standard deviation.

\section{Results}

The data showed no significant difference in initial and post training weight between experimental ( $\mathrm{p}=$ $0.840)$ and control $(p=0.467)$ groups. Resistance exercise training increased the total content of S1P in plasma $(\mathrm{P}=0.001)$ in comparison with control group (Table1). No significant correlation was found between gene expression of S1P1 receptor and MyoD $(\mathrm{r}=+0.274, \mathrm{p}=0.059)$, while there were significant correlations between gene expression of S1P2 receptor $(\mathrm{r}=+0.894, \mathrm{p}<0.000)$ and $\mathrm{S} 1 \mathrm{P} 3$ receptor $(\mathrm{r}$ $=+0.287, \mathrm{p}=0.048)$ (Figure. 1a).
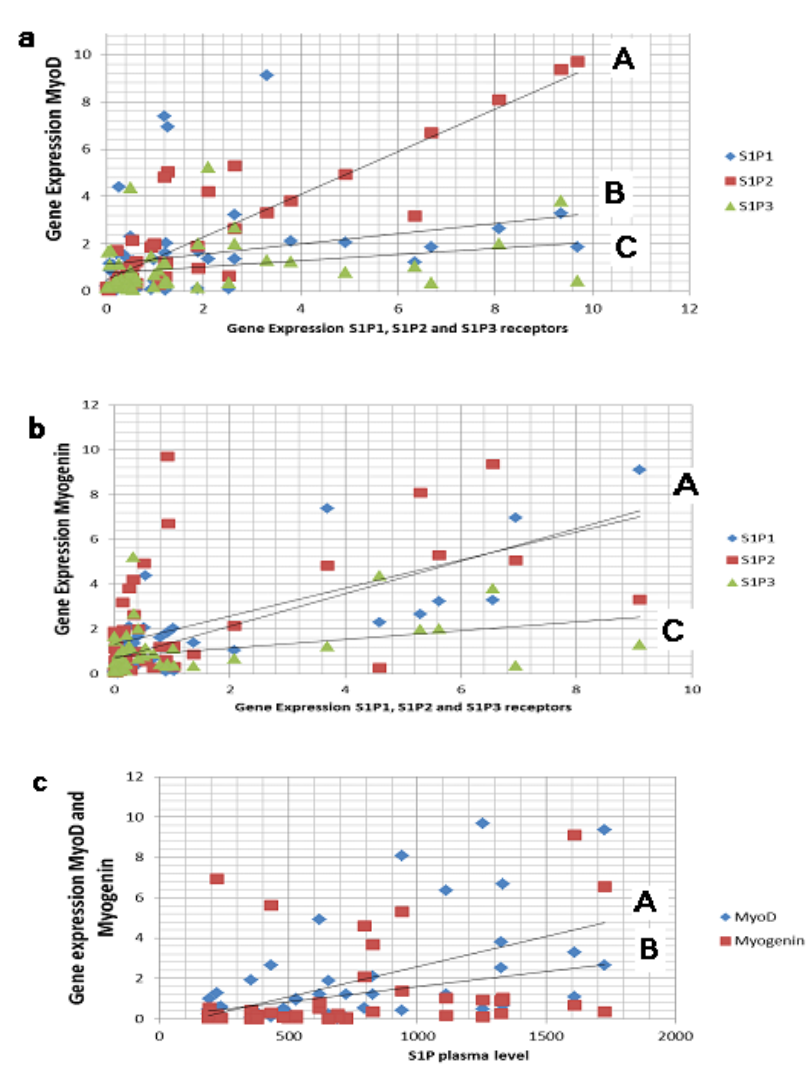

Figure 1. Correlation between MyoD and S1P receptors (S1P1, $\mathrm{S} 1 \mathrm{P} 2$ and S1P3). (A) There is significant correlation between gene expression of MyoD and S1P2 receptor $(r=+0.894, p=0.000)$. (B) There is significant correlation between gene expression of MyoD and $\mathrm{S} 1 \mathrm{P} 3$ receptor $(\mathrm{r}=+0.287, \mathrm{p}=0.048)$. (C) There is no significant correlation between gene expression of $\mathrm{MyoD}$ and S1P1 receptor $(\mathrm{r}=+0.274, \mathrm{p}=0.059) \quad(\mathrm{P}<0.05) \quad$ (Figure 1a). Correlation between Myogenin and S1P receptors (S1P1, S1P2 and S1P3). (A) There is significant correlation between gene expression of Myogenin and S1P1 receptor $(\mathrm{r}=+0.804, \mathrm{p}=0.000)$. (B) There is significant correlation between gene expression of Myogenin and S1P2 receptor $(r=+0.544, p=0.000)$. (C) There is significant correlation between gene expression of Myogenin and S1P3 receptor $(\mathrm{r}=+0.378, \mathrm{p}=0.008) \quad(\mathrm{P}<0.05) \quad$ (Figure 1b). Correlation between Myogenic regulatory factors (MRFs) and S1P plasma level. (A) There is significant correlation between S1P plasma level and gene expression of MyoD $(r=+0.554, p=0.000)$ and $(\mathrm{B})$ gene expression myogenin $(\mathrm{r}=+0.315, \mathrm{p}=0.029)(\mathrm{P}<0.05)$ (Figure 1c).

Significant correlation was seen between gene expression of S1P1 receptor and myogenin ( $r=$ 
$+0.804, \mathrm{p}<0.000)$. There was significant correlations between gene expression of S1P3 receptor and myogenin $(r=+0.378, p=0.008)$. Also, significant correlation between gene expression of S1P2 receptor and myogenin $(\mathrm{r}=+0.544, \mathrm{p}<0.000)$ was observed (Figure. 1b).

There were significant correlations between plasma S1P level and gene expressions of MyoD ( $\mathrm{r}=+0.554$, $\mathrm{p}<0.000)$ and myogenin $(\mathrm{r}=+0.315, \mathrm{p}=0.029)$ (Figure. 1c).

\section{Discussion}

The results showed significant correlations between plasma S1P and genes expressions of MyoD and myogenin. Some researchers assume S1P as a trophic factor, as this factor can increase gene expression of MyoD and decrease athrophy-induced by denervation $(12,27)$. S1P and sphingosine were found to increase gene expression levels of MyoD and myogenin in denervated muscles (12). Our results showed significant positive correlations between MyoD, myogenin and plasma S1P levels which was in agreement with those of Zanin et al. that showed the presence of S1P and sphingosine during denervation caused large increases of MyoD and myogenin expression (12).

Current study showed that there was no significant correlation between S1P1 receptor and gene expression of MyoD. But there was a significant correlation between $\mathrm{S} 1 \mathrm{P} 1$ receptor and gene expression of myogenin. Based on the findings of Adams et al. myogenin is responsible for cell differentiation (28). In addition, S1P1 mostly couples to $\mathrm{Gi}$ and Ras-Raf-MAPkinase (mitogen activated protein kinase) pathways and leads to morphogenetic differentiation (29). So, gene expression of S1P1 receptor and myogenin that are significantly correlated may induce differentiation after training. There was also significant correlation between S1P2 receptor and gene expression of MyoD. Previous studies have shown that MyoD is a proliferator factor (30-32). Also, Donati et al. illustrated that proliferative response to S1P was mediated mainly by S1P2 (18). Thus, a positive interaction seems to exist between gene expression of MyoD and S1PR2 that are proliferative factors. Present data showed a correlation between S1P3 receptor and gene expression of MyoD. Furthermore, there was a significant correlation between S1P3 receptor and gene expression of myogenin. It seems that S1P3 similar to S1P1 is involved in cell differentiation following resistance training.

A noteworthy result of the current study was that there were no significant correlations between plasma S1P and gene expression of myogenic regulatory factors (MyoD and myogenin). MyoD and myogenin are myogenic regulatory factors (MRFs) (3), and markers of satellite cell activation. It should be noted that plasma S1P is sufficient to fully occupy the majority of S1PRs (18). So, it could be speculated that $\mathrm{S} 1 \mathrm{P}$ receptors are more important in myogenic signaling than plasma S1P level itself. Our results demonstrate that $\mathrm{S} 1 \mathrm{P}$ receptors are expressed at skeletal muscle and they seemed to be effective candidates in mediating the growth effects of S1P after resistance training. The present work demonstrates, for the first time, findings on gene expression of MyoD, myogenin and S1P1, 2, 3 receptors in fast (FHL) and slow (SOL) twitch skeletal muscles and S1P content in plasma after 8 weeks resistance training in male Wistar rats. The results clearly show that resistance exercise training markedly affects the S1P levels in plasma. To the best of our knowledge no data in the literature are available on resistance training to be compared with these results, however few studies in which acute and prolonged endurance exercises are used might help. Blachnio-Zabielska et al. showed that acute endurance training increases the content of S1P in the soleus and the red gastrocnemius (33). It has been shown that insulin, cytokines and growth factors, such as PDGF, EGF, IGF-1 activate SK1 acutely, resulting in transient increase of $\operatorname{S1P}(15,34,35)$. Trenerry et al. (2011) illustrated that after resistance training protein expression of PDGF-BB increased in skeletal muscle (36). Prolonged resistance training increased resting IGF-1 concentrations (38-40). It seems that increased platelet activity and/or platelet count following eight weeks of resistance training caused the increase of S1P levels in plasma $(41,42)$. Ahmadizad et al. indicated significant increase in platelet count in response to resistance training (43). $\mathrm{S} 1 \mathrm{P}$ is likely to be such mediator because it is released from activated platelets and leads to mitogenic effects (44). All these might be due to the resistance training.

In support of our research findings, de la GarzaRodea et al. showed that S1P/SPL/S1P-receptor axis plays major roles in expression of a number of miRNAs and myogenic differentiation in cell line (45).

In another study, Sassoli et al. illustrated that SK1 activity and endogenous S1P levels were significantly higher in the injured fibers which seemed to be associated to satellite stem cells (46). Together, these findings indicate an important role for $\mathrm{S} 1 \mathrm{P}$ in regeneration of skeletal muscle and its adaptation to resistance training. Danieli-Betto et al. demonstrated that S1P may be released to the sites of tissue injury and stimulate cellular repair responses (20). Furthermore, resistance training increased gene expression of S1P1, S1P2 and S1P3 of FHL and SOL 
in experimental group compared to that in control group. Zanin et al. have shown that the gene expression of S1P1, 3 receptors significantly decreased during muscle denervation (12). As denervation causes inactivity and this might lead to decrease in gene expression of S1P receptors, it might be reasonable that resistance training which activates muscles has increased gene expression of these receptors as shown in this study. Resistance training significantly increased gene expression of MyoD in trained fast twitch FHL and slow twitch soleus muscles comapred to that of the control group. Furthermore, 8 weeks resistance training significantly increased gene expression of myogenin in trained FHL and SOL compared with control group. MyoD is an essential factor for proliferation whereas myogenin is an important factor in myogenic differentiation (47).

We have shown correlations between satellite cells activation markers (MyoD and myogenin) and plasma S1P content and its receptors before and after resistance training which might strengthen the trophic/myogenic role of S1P system in skeletal muscle.

\section{Acknowledgements}

The authors thank Tarbiat Modares Univrsity and clinical biochemistry research center of Shahrekord University of Medical Sciences for their supports.

\section{Author contributions}

All authors have made substantial contributions to the conception and design of the study, doing the experiments, acquisition or statistical analysis and interpretation of data. All authors also contributed in final approval of the version of manuscript.

\section{Support/Funding}

This work was supported by the Tarbiat Modares University.

\section{Conflict of Interest}

There is no conflict for present study.

\section{References}

1. Adams MM, Hicks AL. Comparison of the effects of bodyweight-supported treadmill training and tilt-table standing on spasticity in individuals with chronic spinal cord injury. J Spinal Cord Med. 2011; 34(5):488-94. PMID: 22118256

2. Costa A, Dalloul H, Hegyesi H, Apor P, Csende Z, Racz L, et al. Impact of repeated bouts of eccentric exercise on myogenic gene expression. Euro J Appl Physiol. 2007; 101 (4):427-36. PMID: 17641910

3. Dedkov EI, Kostrominova TY, Borisov AB, Carlson BM. MyoD and myogenin protein expression in skeletal muscles of senile rats. Cell Tissue Res. 2003; 311(3):401-16. PMID: 12658448
4. Brian S, Matt C, Thomas B, Geoffrey H, Liz R, Brian L, et al. Effects of 28 days of resistance exercise and consuming a commercially available pre-workout supplement, NO-ShotgunÂ, on body composition, muscle strength and mass, markers of satellite cell activation, and clinical safety markers in males. J Int Soc Sports Nut. 2009; 6(1):1.

5. Dyatlovitskaya EV. The role of lysosphingolipids in the regulation of biological processes. Biochemistry (Mosc). 2007; 72(5):479-84. PMID: 17573701

6. Zeidan YH, Hannun YA. Translational aspects of sphingolipid metabolism. Trends Mol Med. 2007; 13(8):327-36. PMID: 17588815

7. Igarashi J, Erwin PA, Dantas APV, Chen H, Michel T. VEGF induces S1P1 receptors in endothelial cells: Implications for crosstalk between sphingolipid and growth factor receptors. Proc Natl Acad Sci U S A. 2003; 100(19):10664-9. PMID: 12963813

8. Lahiri S, Futerman AH. The metabolism and function of sphingolipids and glycosphingolipids. Cell Mol Life Sci. 2007; 64(17):2270-84. PMID: 17558466

9. Sanchez T, Hla T. Structural and functional characteristics of S1P receptors. J Cell Biochem. 2004; 92(5):913-22. PMID: 15258915

10. Venkataraman K, Lee YM, Michaud J, Thangada S, Ai Y, Bonkovsky HL, et al. Vascular endothelium as a contributor of plasma sphingosine 1-phosphate. Circ Rese. 2008; 102(6):669. PMID: 18258856

11. Graler MH. Targeting sphingosine 1-phosphate (S1P) levels and S1P receptor functions for therapeutic immune interventions. Cell Physiol Biochem.2010; 26(1):79-86. PMID: 20502007

12. Zanin M, Germinario E, Dalla Libera L, Sandonà D, Sabbadini RA, Betto R, et al. Trophic action of sphingosine 1-phosphate in denervated rat soleus muscle. Am J Physiol Cell Physiol. 2008; 294(1):C36. PMID: 17942639

13. Nagata Y, Partridge TA, Matsuda R, Zammit PS. Entry of muscle satellite cells into the cell cycle requires sphingolipid signaling. J Cell Biol. 2006; 174(2):245-53. PMID: 16847102

14. Nagata Y, Kobayashi H, Umeda M, Ohta N, Kawashima S, Zammit PS, et al. Sphingomyelin levels in the plasma membrane correlate with the activation state of muscle satellite cells. J Histochem Cytochem. 2006; 54(4):375. PMID: 16400000

15. Kim RH, Takabe K, Milstien S, Spiegel S. Export and functions of sphingosine-1-phosphate. Biochim Biophysica Acta. 2009; 1791(7):692-6. PMID: 19268560

16. Donati C, Bruni P. Sphingosine 1-phosphate regulates cytoskeleton dynamics: implications in its biological response. Biochimica Biophys Acta. 2006; 1758(12):2037-48. PMID: 16890187

17. Sassoli C1, Formigli L, Bini F, Tani A, Squecco R, Battistini $\mathrm{C}$, et al. Effects of S1P on skeletal muscle repair/regeneration during eccentric contraction. J Cell Mol Med. 2011; 15(11):2498511. PMID: 21199328

18. Donati C, Cencetti F, Nincheri P, Bernacchioni C, Brunelli S, Clementi E, et al. Sphingosine 1 Phosphate Mediates Proliferation and Survival of Mesoangioblasts. Stem Cells. 2007; 25(7):1713-9. PMID: 17464089 
19. Loh KC, Leong WI, Carlson ME, Oskouian B, Kumar A, Fyrst $\mathrm{H}$, et al. Sphingosine-1-Phosphate Enhances Satellite Cell Activation in Dystrophic Muscles through a S1PR2/STAT3 Signaling Pathway. PLoS One. 2012; 7(5):e37218. PMID: 22606352

20. Danieli-Betto D, Peron S, Germinario E, Zanin M, Sorci G, Franzoso S, et al. Sphingosine 1-phosphate signaling is involved in skeletal muscle regeneration. Am J Physiol Cell Physiol. 2010; 298(3):C550-8. PMID: 20042733

21. Donati C, Meacci E, Nuti F, Becciolini L, Farnararo M, Bruni P. Sphingosine 1-phosphate regulates myogenic differentiation: a major role for S1P2 receptor. FASEB J. 2005; 19(3):449-51. PMID: 15625079

22. Lee S, Farrar RP. Resistance training induces muscle-specific changes in muscle mass and function in rat. J Exercise Physiol Online. 2003; 6(2):80-7.

23. Barton-Davis ER, Shoturma DI, Musaro A, Rosenthal N, Sweeney HL. Viral mediated expression of insulin-like growth factor I blocks the aging-related loss of skeletal muscle function. Proc Natl Acad Sci U S A. 1998; 95(26):15603. PMID: 9861016

24. Duncan ND, Williams DA, Lynch GS. Adaptations in rat skeletal muscle following long-term resistance exercise training. Euro J Appl Physiol Occup Physiol. 1998; 77(4):372-8. PMID: 9562367

25. Min JK, Yoo HS, Lee EY, Lee WJ, Lee YM. Simultaneous quantitative analysis of sphingoid base 1-phosphates in biological samples by o-phthalaldehyde precolumn derivatization after dephosphorylation with alkaline phosphatase. Anal Biochem. 2002; 303(2):167-75. PMID: 11950216

26. Parise G, Brose AN, Tarnopolsky MA. Resistance exercise training decreases oxidative damage to DNA and increases cytochrome oxidase activity in older adults. Exp Gerontol. 2005; 40(3):173-80. PMID: 15763394

27. Safdar A, Yardley NJ, Snow R, Melov S, Tarnopolsky MA. Global and targeted gene expression and protein content in skeletal muscle of young men following short-term creatine monohydrate supplementation. Physiol Genomics. 2008; 32(2):219. PMID: 17957000

28. Adams GR, Haddad F, Baldwin KM. Time course of changes in markers of myogenesis in overloaded rat skeletal muscles. J Appl Physiol. 1999; 87(5):1705. PMID: 10562612

29. Im DS, Tomura H, Tobe M, Sato K, Okajima F. Enhancement of sphingosine 1-phosphate-induced phospholipase $\mathrm{C}$ activation during G 0-G 1 transition in rat hepatocytes. J Pharmacol Sci. 2004; 95(2):284-90. PMID: 15215654

30. Pietrangelo T, Puglielli C, Mancinelli R, Beccafico S, Fan G, Fulle S. Molecular basis of the myogenic profile of aged human skeletal muscle satellite cells during differentiation. Exp Gerontol. 2009; 44(8):523-31. PMID: 19457451

31. Raue U, Slivka D, Jemiolo B, Hollon C, Trappe S. Myogenic gene expression at rest and after a bout of resistance exercise in young (18-30 yr) and old (80-89 yr) women. J Appl Physiol. 2006; 101(1):53. PMID: 16601301

32. Tidball JG. Mechanical signal transduction in skeletal muscle growth and adaptation. J Appl Physiol. 2005; 98(5):1900-8. PMID: 15829723
33. B achnio Zabielska A, Baranowski M, Zabielski P, Górski J. Effect of exercise duration on the key pathways of ceramide metabolism in rat skeletal muscles. J Cell Biochem. 2008; 105(3):776-84. PMID: 18680146

34. Hannun YA, Obeid LM. Principles of bioactive lipid signalling: lessons from sphingolipids. Nat Rev Mol Cell Biol. 2008; 9(2):139-50. PMID: 18216770

35. Bencini C, Squecco R, Piperio C, Formigli L, Meacci E, Nosi $\mathrm{D}$, et al. Effects of sphingosine 1-phosphate on excitationcontraction coupling in mammalian skeletal muscle. J Muscle Res Cell Motil. 2003; 24(8):539-54. PMID: 14870969

36. Trenerry MK, Carey KA, Ward AC, Farnfield MM, CameronSmith D. Exercise-induced activation of STAT3 signaling is increased with age. Rejuvenation Res. 2008; 11(4):717-24. PMID: 18729804

37. Young N, Van Brocklyn JR. Signal Transduction of Sphingosine-1-Phosphate G Protein-Coupled Receptors. ScientificWorldJournal. 2006; 6:946-66. PMID: 16906327

38. Kraemer WJ, Ratamess NA. Hormonal responses and adaptations to resistance exercise and training. Sports Med. 2005; 35(4):339-61. PMID: 15831061

39. Marx JO, Ratamess NA, Nindl BC, Gotshalk LA, Volek JS, Dohi K, et al. Low-volume circuit versus high-volume periodized resistance training in women. Med Sci Sports Exerc. 2001; 33(4):635-43. PMID: 11283441

40. Borst SE, De Hoyos DV, Garzarella L, Vincent K, Pollock BH, Lowenthal DT, et al. Effects of resistance training on insulin-like growth factor-I and IGF binding proteins. Med Sci Sports Exerc. 2001; 33(4):648. PMID: 11283443

41. Dyatlovitskaya EV, Kandyba AG. Bioeffector Sphingolipids as Stimulators of Cell Growth and Survival. Russ J Bioorganic Chem. 2004; 30(3):201-6.

42. Hilberg T, Glaser D, Koksch M, Schmidt V, Sossdorf M, Gabriel HHW. Differentiation of platelet-leukocyte conjugate formation by short term exercise. Clin Hemorheol Microcirc. 2004; 31(3):217-26. PMID: 15322327

43. Ahmadizad S, El-Sayed MS, MacLaren DPM. Responses of platelet activation and function to a single bout of resistance exercise and recovery. Clin Hemorheol Microcirc. 2006; 35(1):159-68. PMID: 16899922

44. Ishii I, Fukushima N, Ye X, Chun J. Lysophospholipid receptors: signaling and biology. Annu Rev Biochem. 2004; 73(1):321-54. PMID: 15189145

45. Anabel S, Baldwin DM, Oskouian B, Place RF, Bandhuvula P, Kumar A, et al. Sphingosine phosphate lyase regulates myogenic differentiation via S1P receptor-mediated effects on myogenic microRNA expression. The FASEB J. 2014; 28(1):506-19. PMID: 24158395

46. Sassoli C, Formigli L, Bini F, Tani A, Squecco R, Battistini C, et al. Effects of S1P on skeletal muscle repair/regeneration during eccentric contraction. J Cell Mol Med. 2011; 15(11):2498-511. PMID: 24158395

47. Stewart CEH, Rittweger J. Adaptive processes in skeletal muscle: molecular regulators and genetic influences. Journal of Musculoskelet Neuronal Interact. 2006; 6(1):73. PMID: 16675891 